\title{
高齢者医療に貢献するリン脂質ポリマー
}

\section{Phospholipid Polymers for Contributing to Elderly Persons Medical Care}

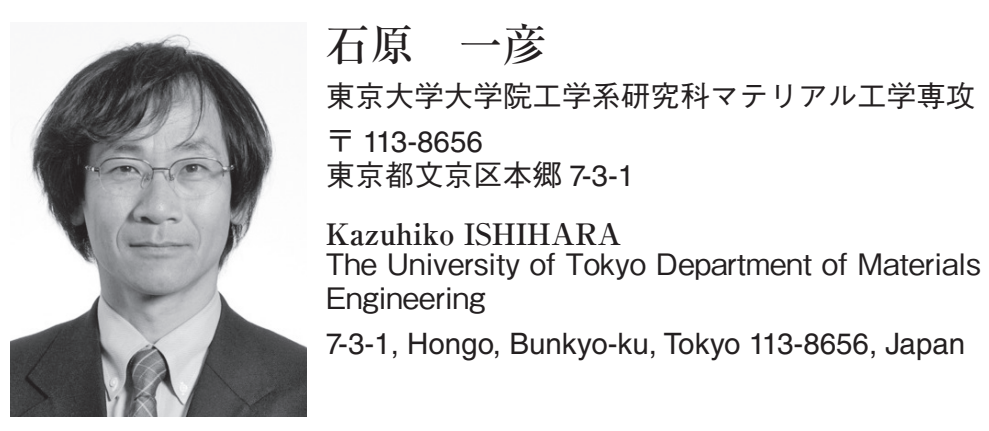

論文要旨：生体内埋め込み型医療デバイスの表面処理について解説する。一般の材料は生体組織と接触す ると様々な好ましくない生体反応を誘起する。これが，埋め込み型医療デバイスを利用した治療に大きな問 題となっている。特に高齢者に対しては, 安全・安心な医療を提供するという観点からは, 生体親和性の高 いバイオマテリアルが求められる。表面の特性を改善するために, 細胞膜表面の構造に着目し, リン脂質極 性基を有するポリマー，2-メタクリロイルオキシエチルホスホリルコリン（MPC）ポリマーを創製した。 このポリマーを利用して，運動器障害の修復に利用する人工股関節の寿命延長を試みた。すなわち，関節慴 動面における摩耗を低減し，摩耗粉による生体反応を低減する試みである。人工股関節に利用されている架 橋ポリエチレン（CLPE）にMPCをグラフトすることで，表面にポリマー層を構築すると，摩擦抵抗が激 減し，これに対応して摩耗がほぼ抑制された。また，人工関節周辺の骨溶解も抑制され，人工股関節置換手 術の寿命の延長が見込まれた。現在，日本において臨床使用できるようになり，高齢者医療に貢献している。

\begin{abstract}
In this review, surface treatment on the implantable medical devices with phospholipid polymers is described. Conventional polymer materials using in the biomedical field do not have enough biocompatibility and blood compatibility; therefore, infusion of an anticoagulant is required during clinical treatments when using these medical devices, to avoid biological responses. To improve their properties, some surface modification methods using newly designed a phospholipid polymer, 2-methacryloyloxyethyl phosphorylcholine (MPC) polymer, which is prepared with inspiration from cell membrane surface. Improvement of the bio/blood compatibility of the medical devices using the MPC polymers to suppress unfavorable biological responses at the interface between the medical devices and living organisms are explained. A novel artificial joint system has been developed with MPC polymer grafted onto the surface of cross-linked polyethylene (CLPE), which is used as a liner of artificial joint (CLPE-g-MPC). The MPC grafting on the surface of CLPE liner markedly decrease the friction and the wear. The MPC grafting can successfully inhibit the bone resorptive response to wear particles to levels similar to those of recently developed pharmacological therapies such as cytokine antagonists and osteoprotegerin. This new type artificial hip joint has been implanted to patients in Japan to obtain good clinical results.
\end{abstract}

Key words: Biomaterials, Phospholipid polymer, Biocompatibility, Artificial hip joint, Lubrication

\section{1 はじめに}

バイオテクノロジーの急速な進歩と生み出される革新 的技術が 21 世紀の社会を大きく変えていくことが期待 されている。例えばヒトゲノムの解析が有用な機能夕ン

連絡者：石原一彦

E-mail : ishihara@mpc.t.u-tokyo.ac.jp
パク質, ホルモンなど体調の維持管理, 疾病の診断, 治 療へ応用されようとしており，大きな産業育成も見达ま れている。これらより，特に世界的に高齢社会に向かっ ている現状から，高齢者を対象とした低侵襲医療はもと より,今後,さらに各人の特性にあったオーダーメイド 治療, 患部のみを治療するピンポイント治療, 分子, 細 胞を標的としたナノ医療, また医療デバイスの機能向上 


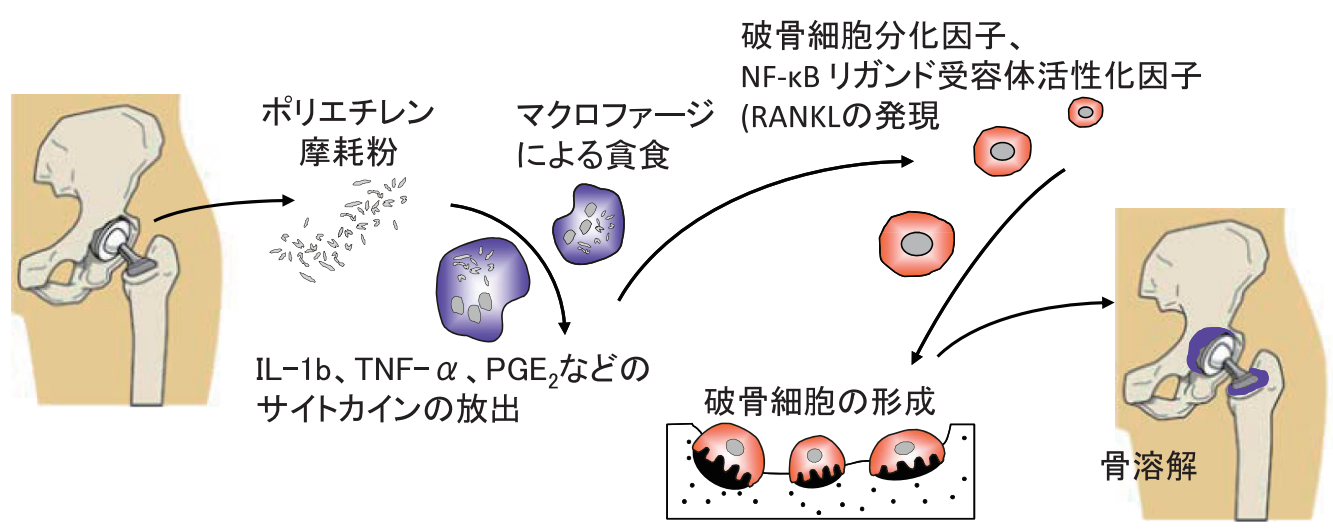

Fig. 1 超高分子量ポリエチレン製ライナーの摩耗から始まる骨溶解過程。

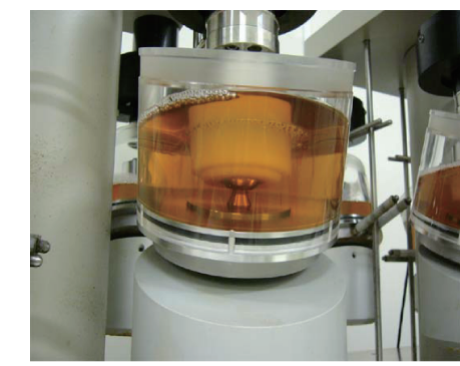

人工股関節シミュレーター 負荷 : $280 \mathrm{kgf}$

周期: $1 \mathrm{~Hz}$

媒体: 25\%血清

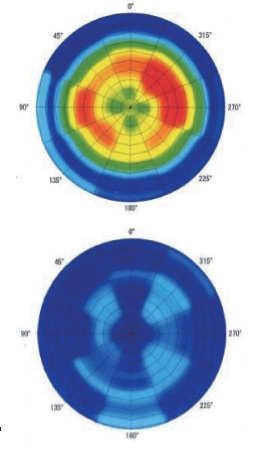

ポリエチレン

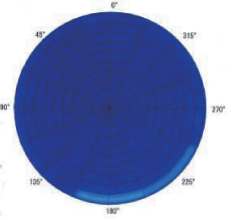

MPCポリマー処理

架橋ポリエチレン

Fig. 5 表面粗さ測定による三次元解析結果。

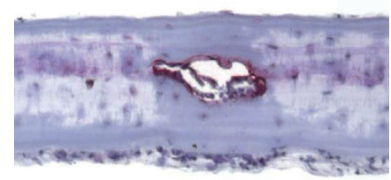

未処理骨組織

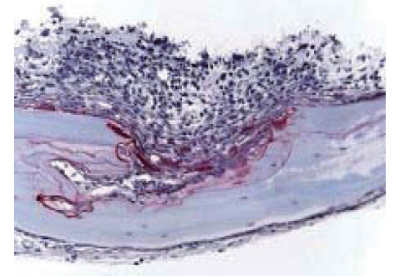

ポリエチレン粒子を 接触させた骨組織

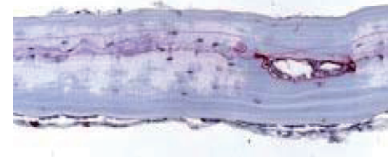

MPCポリマー処理 ポリエチレン粒子 を接触させた骨組 織

Fig. 7 ポリマー粒子（摩耗粉）が骨組織に与える影響。

にもとづいた先端医療が強く求められるようになってき ている。さらに在宅での日々の健康管理や在宅治療に役 立つデバイスの開発も，医療費の爆発的な高騰を抑制す るための予防医療を発展させるであろう。このような状 況を考えると，生体あるいは生体成分（細胞，バイオ分
子）と接触して利用される材料, いわゆる安全に利用で きるバイオマテリアルの有用性がますます高まることは 容易に考えられることである。 


\section{2 高齢者の運動器系機能の修復と問題点}

生体組織の機能が低下したり，不全になったりした場 合には，その機能を代替する医療デバイス，いわゆる人 工臓器が適用される。完全な生体機能の修復が達成でき ない場合も多いが, 中には成功して患者の QOL の改善 の役割を充分に果たしている場合も少なくない ${ }^{1-3)}$ 。

人工股関節置換術は, 変形性関節症, 突発性大腿骨頭 壊死，関節リウマチ，外傷などで喪失した関節の機能を 再建し, 疼痛を寛解する優れた治療法であり, 高齢社会 を迎えた我が国においては，手術件数が年々増加してい る。国内では，年間約 8〜9 万件の手術が行われているが, その件数は今後も前年比 110\%で増加するとされている ${ }^{4)}$ 。 また, 米国では 2010 年に約 91 万件の手術が行われたが, 2030 年には約 405 万件に急増するとされている。しかし， 医療技術の進歩と社会基盤の整備などで平均寿命が高く なりつつある一方で, 人工関節の耐用年数 (寿命) は一 般に約 10〜15 年であり，手術を受けた患者は生涯のう ちに人工関節の入れ換えの手術（人工関節再置換術）が 必要となる。この人工関節再置換術は, 患者やその家族 に大きな負担を強いることになるため, 従来 60 歳以上 の比較的高齢の患者を対象としてきた。しかし，患者の 価值観や QOL が尊重されるようになり，40歳代後半か ら 50 歳代でも, 快適な生活をおくるための一手段とし て人工関節置換術が選択されることも少なくない。すな わち，活動性が高く充実した生活を実現するために人工 関節の果たす役割は大きく, その長寿命化は必須である。

しかし, 手術後に生じる弛みはその長期予後を決定す る最大の合併症である。弛みは人工関節周囲の骨吸収を 伴い進行性であり, 疼痛や歩行障害を引き起こすため, 再置換手術が必要になる。したがって, 人工股関節手術 を受けた患者は再置換術の潜在的な対象であり，人口の 高齢化が進む我が国においてはその件数は今後増加し続 けると予想される。弛みの過程は, 関節摺動面を構成す る超高分子量ポリエチレン製ライナーが骨頭との摩擦に より摩耗し, 微小摩耗粉を生じることから始まる。この 摩耗粉はマクロファージに貪食される。このために, マ クロファージが活性化しサイトカインやプロスタグラン ジンなどを分泌する。これらの生体活性物質は周囲の間 葉系細胞に作用し, 破骨細胞分化因子や NF-кB リガン ド受容体活性化因子（RANKL）の発現を誘導する。そ の結果，破骨細胞の形成・活性が促進され，人工股関節 周囲の骨吸収に至る (Fig. 1 $)^{5)}$ 。したがって，現在まで の弛み抑制のための研究は, 摩耗粉を減少させること, あるいは，骨吸収を抑制すること，の２つの方向性で検 討されてきた。摩耗粉を減少させる試みとしては, ポリ
エチレンの改質やポリエチレンを使わない人工関節の開 発などが進められてきている。ポリエチレンを高温・高 圧で処理し，結晶化率を高める試みは実用化に至ったも のの短期間に弛みが生じ失敗に終わった。 $\gamma$ 線照射をす ることでポリエチレンの非晶部分を架橋させた架橋ポリ エチレンは, 摩耗の抑制には有効であるものの, 摩耗粉 が骨吸収を誘導するという問題は全く解決されていな い。金属／金属の摺動（しゅうどう）面を持つ人工関節 は金属イオンの毒性の問題が指摘されており，セラミッ クスの人工関節は少数ではあるが体内での破損例も報告 されている。また，骨吸収を抑制する試みとしては，抗 サイトカイン抗体などを用いた薬物治療や遺伝子治療が 研究されているが，全身への影響による副作用が避けら れない問題として残っている。以上のように, 弛みの抑 制のため, 数多くの研究開発が行われてきたが, 摩耗と 骨吸収のどちらかの抑制を目指した研究では，決定的な 解決策を得るには至っていない。したがって, その双方 の抑制を同時にかなえることができる人工股関節の開発 研究が強く求められている。

\section{3 リン脂質ポリマーによるバイオミミック界面の創製}

筆者らは, ポリマーバイオマテリアルの開発の過程で, 細胞膜表面構造を人工的に構築するためにリン脂質極性 基を側鎖に結合したメタクリル酸エステル，2-メタクリ ロイルオキシエチルホスホリルコリン（MPC : Fig. 2)

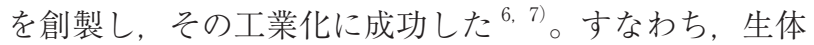
親和性表面として理想的で, 模範となるものは血管内皮 細胞表面と考えられる。正常な血管内表面では, 細胞は もとよりタンパク質の吸着, 活性化は生起しない。一方, 材料が血液と接触すると血液凝固反応や免疫反応など生 命防御のために生体反応が引き起こされる。そこで細胞 膜表面の構造あるいは性質をうまく材料に組み込めばこ の生体反応の制御が可能と考えるのは至極当然である。 細胞膜表面はリン脂質分子の二分子膜中にタンパク質が モザイクのようにはめ込まれ，また表面から外側に向 かって親水性の多糖が出ている。細胞膜での生体反応の ほとんどはタンパク質が関与し, その構造変化や分布状 態の変化により外部からの信号が細胞内に伝達される。

多糖も外部の信号を受容するアンテナ分子として働いて いる。これらに対して，リン脂質分子は機能分子である タンパク質を一定の空間位置に配置する役割，すなわち マトリックスとして働いているにすぎない。リン脂質分 子の極性基が細胞内外で大きく異なっていることが知ら れている。他の分子や組織と接触する機会の多い細胞外 側では中性の極性基であるホスホリルコリン（PC）基 を持つリン脂質（ホスファチジルコリン，スフィンゴミ 
エリン）が多い。一方，細胞膜内面に存在するリン脂質 はホスファチジルエタノールアミンやホスファチジルセ リンで，いずれも酸性脂質である。すなわち，細胞膜の 外表面は中性のリン脂質分子を配列させて，明らかに生 体反応の不活性な場を作り出している。

また，生体の関節軟骨表面にはナノスケールのリン脂質 の層が存在し，表面潤滑の改善の役割を果たしている ${ }^{8)}$ 。 そこで, MPCポリマーを利用して人工細胞膜表面を関節 摺動面に作成することによる表面機能化を目指した ${ }^{9)}$ 。

金属，セラミックスのようないわゆる硬い材料は，人 工関節など運動系人工臓器や人工歯根，人工骨あるいは 欠損部を補填する補綴（ほてつ）材として歯科，整形外 科治療に利用されてきた。これらは強度や加工性が主た る選択の理由となってきていたが, 最近では循環器系人 工臓器として金属が利用されるようになり，力学的特性 以外にも表面における血液凝固反応の阻止や, 埋め込み 部位によっては軟組織との適合性が強く求められてい る。これら生体環境において役割を果たすことができ， かつ生体に悪影響を与えない材料は医療デバイスを開発 する際に不可欠である ${ }^{2)}$

\section{4 リン脂質ポリマーによる超潤滑慴動面を実装した人 工股関節}

筆者らは, 高齢社会に対応する医療を支える高機能医 療デバイスを開発するために不可欠な表面のポリマーナ ノ処理を考えた。人工股関節の弛みの抑制のため，ポリ エチレンライナー表面へ MPC ポリマーをグラフト重合 させる手法を創案した（MPC ポリマー処理）。この処理 は，紫外線を用いて，MPCポリマー鎖とポリエチレン の炭素原子同士に安定な共有結合をさせるもので，表層 のみの処理であり，基材であるポリエチレン自体には影 響を及ぼさない 9,10)。具体的には，光増感剤であるべン ゾフェノンをポリエチレンライナー上に吸着させ，これ をMPC モノマー溶液に浸漬した。これに $350 \mathrm{~nm}$ 程度 の紫外光を照射することにより，ベンゾフェノンを活性 化し，水素引き抜き反応を誘起させた。これによりポリ エチレン表面にラジカルが生じ，これを開始点として MPCの重合が進行する。結果として，MPC ポリマー鎖 がグラフトされる。電界放射型透過電子顕微鏡 (FETEM）による表面観察で，その処理厚みが約 100 $150 \mathrm{~nm}$ と, ナノスケールであることが明らかになって いる (Fig. 3)。

筆者らは人工股関節のポリエチレンライナー表面の MPC ポリマーによるナノ表面処理が弛みの阻止に与え る影響を，耐摩耗性と摩耗粉が骨吸収に与える影響の観 点から検討し，人工股関節の寿命を飛躍的に延長し得る

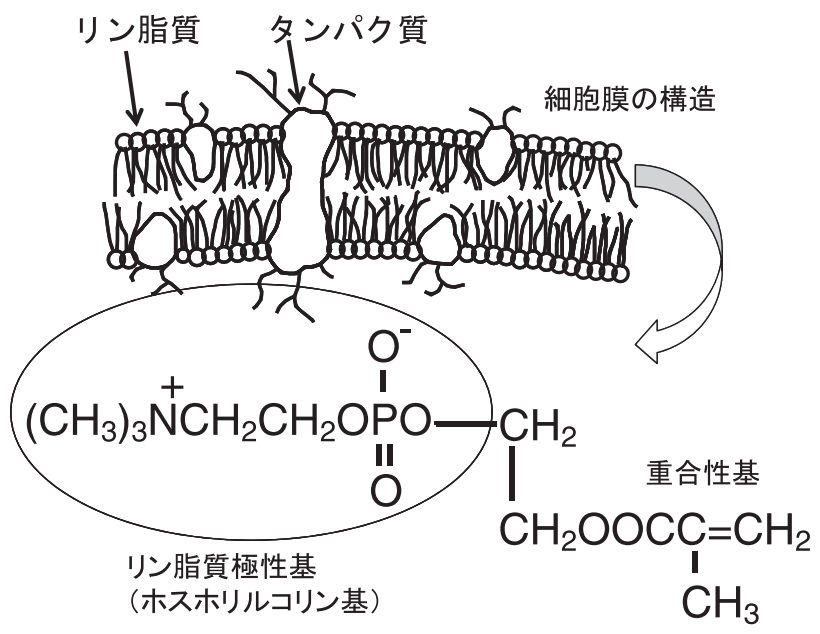

Fig. 2 細胞膜リン脂質構造から発案された2-メタクリロイ ルオキシエチルホスホリルコリン（MPC）。

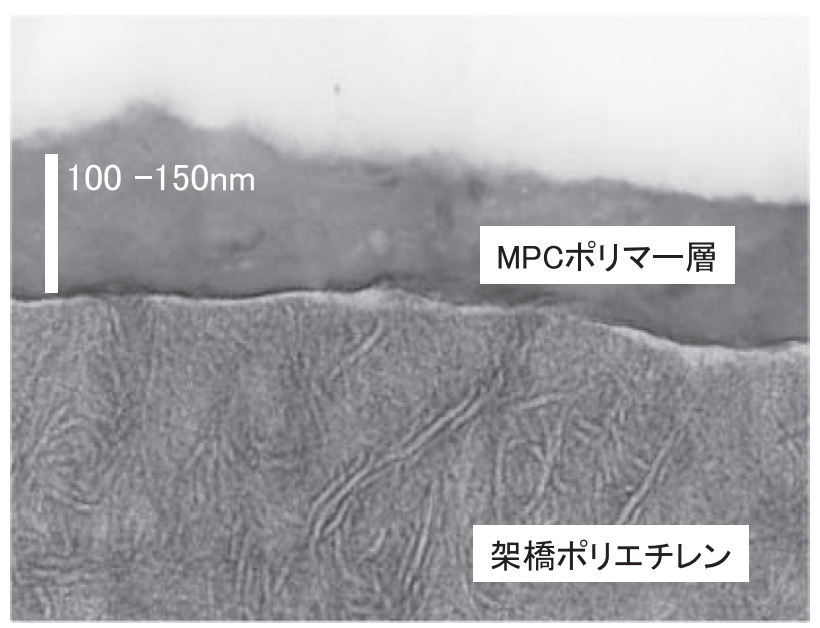

Fig. 3 MPC ポリマーをグラフトレたポリエチレンライナー の表面（FE-TEM による断面像）。

知見を得た ${ }^{11)}$ 。

生体の股関節は，その歩行周期の中で様々な方向から 体重の数倍の負荷を受ける。そこで, より生体内に近い 環境下での耐摩耗効果を観察するため, 連続 2,000万サ イクルの股関節シミュレーター試験（通常の生活にして 約 20 年分）を行った。骨頭にはコバルトクロムモリブ デン合金骨頭（径 $22 \mathrm{~mm}$ ）を用いた。ライナーは架橋 ポリエチレン表面を MPC ポリマー処理したもの（MPC ポリマー処理架橋ポリエチレン）を用い，ポリエチレン および未処理の架橋ポリエチレンと比較した。

ポリエチレン表面は疎水性であるが, 親水性の MPC ポリマーでナノ表面処理することにより，表面の「水な じみ」が改善し，関節摺動面の潤滑機構が向上する。こ のため, 関節摺動面の摩擦トルクを測定すると, MPC ポリマー処理架橋ポリエチレンのトルクは未処理架橋ポ リエチレンの約 $1 / 10$ と低減していた。経時的にライナー 
の重量変化を計測すると, MPC ポリマー処理架橋ポリ エチレンの摩耗量はポリエチレンの $1 / 40$, 架橋ポリエ チレンの $1 / 4$ であった（Fig. 4)。試験終了後のライナー 表面を SEM で観察すると, 未処理群では, 製品加工時 のマシンマークが摩耗により消失していたが, MPC ポ リマー処理架橋ポリエチレンでは残存しており, 摩耗が 著明に抑制されていた。また，ライナー表面を微小粗さ 測定した三次元解析でも, 未処理群では顕著な摩耗が観 察できたのに対し，MPCポリマー処理架橋ポリエチレ ンはほとんど摩耗していなかった（Fig. 5)。ライナー表 面の MPC ポリマー処理効果の残存の有無は, X 線光電 子分光分析装置 (XPS), FE-TEMにより検討した。試 験終了後の MPC ポリマー処理架橋ポリエチレンライ ナー表面をXPS で解析すると, 試験開始前の解析結果 と同様，表面に MPC ユニット特有のリン及び窒素原子 のスペクトルが観察できた。また，試験終了後の MPC ポリマー処理架橋ポリエチレンライナーをFE-TEM で 解析しても, MPC ポリマー処理層は残存していた。

以上のシミュレーター試験により，人工股関節ポリエ チレンライナーの MPC ポリマーによるナノ表面処理 が, 関節摺動面の潤滑機構を改善し, 摩耗粉の産生を著 明に抑制すること，その処理効果は少なくとも連続 2,000 万サイクルの歩行負荷をかけても残存すること, が明ら かになった。

\section{5 生体への適合性について}

シミュレーター試験の潤滑液から摩耗粉を抽出する と, MPCポリマー処理架橋ポリエチレン, 未処理架橋 ポリエチレンとも, 摩耗粉の $95 \%$ 以上はサブミクロン のサイズであり，摩耗粉の粒径分布・形状に明らかな差 は見られなかった。そこで, 平均粒径約 $500 \mathrm{~nm}$ の MPC ポリマー粒子を作製し, MPC ポリマー微小摩耗粉
が骨吸収に与える影響を間接的に検討した。

まず，粒子を蛍光物質で標識し，マウス腹腔内マクロ ファージ培養系に暴露して貪食実験を行った。この結果， 未処理の粒子はマクロファージに大量に貪食されたが, $\mathrm{MPC}$ ポリマー粒子はマクロファージに異物として認識 されず，ほとんど嶺食を受けなかった。ついで， MPC ポリマー粒子あるいは未処理粒子をマウスマクロファー ジ様細胞株・J774.1 細胞に暴露して 24 時間後に培養上 清を回収し, 以下の実験に用いた。まず培養上清中の骨 吸収を誘導するサイトカインの濃度（腫瘍壊死因子

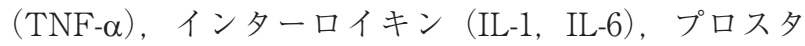
グランジン $\left.\left(\mathrm{PGE}_{2}\right)\right)$ を測定すると，すべての因子にお いて未処理粒子暴露群の濃度は, 溶液のみを加えたコン トロール群と比べ, 4〜 20 倍高值を示したが, MPC ポ リマー粒子暴露群ではこれらの濃度上昇が見られず，対 照群と有意な差が見られなかった（Fig. 6)。つぎに培養 上清をマウス骨芽細胞培養系に添加して RANKLの mRNAの発現を検討した。その結果, 未処理粒子暴露 群ではRANKLの発現を強力に誘導したが，MPCポリ マー処理粒子暴露群では誘導されなかった。さらに培養 上清をマウス骨髄細胞と骨芽細胞の共存培養系に添加し て破骨細胞形成を調べた。未処理群では溶液のみを加え た対照群に比し 7 倍の破骨細胞が形成されたが, MPC ポリマー粒子では対照群と有意な差がみられなかった。

生体内での反応を追跡するために，マウス頭蓋骨上に MPC ポリマー粒子あるいは未処理粒子を移植し，7日 後に頭蓋骨を採取，これを固定・脱灰した後，酒石酸耐 性酸性ホスファターゼ（TRAP）で染色を行った。顕微 鏡にて標本を観察すると, 未処理粒子を移植した群では TRAP 染色陽性の破骨細胞が形成され，骨吸収が強力 に誘導されたが，MPCポリマー粒子を暴露した群では これらが誘導されなかった（Fig. 7)。

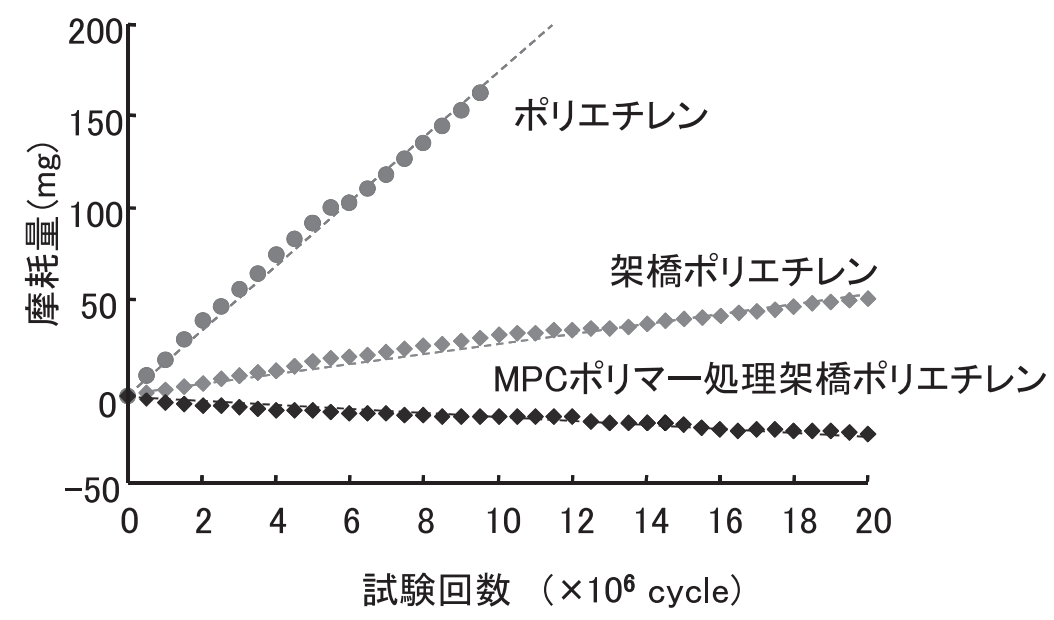

Fig. 4 シミュレーターによる摩耗試験結果。 


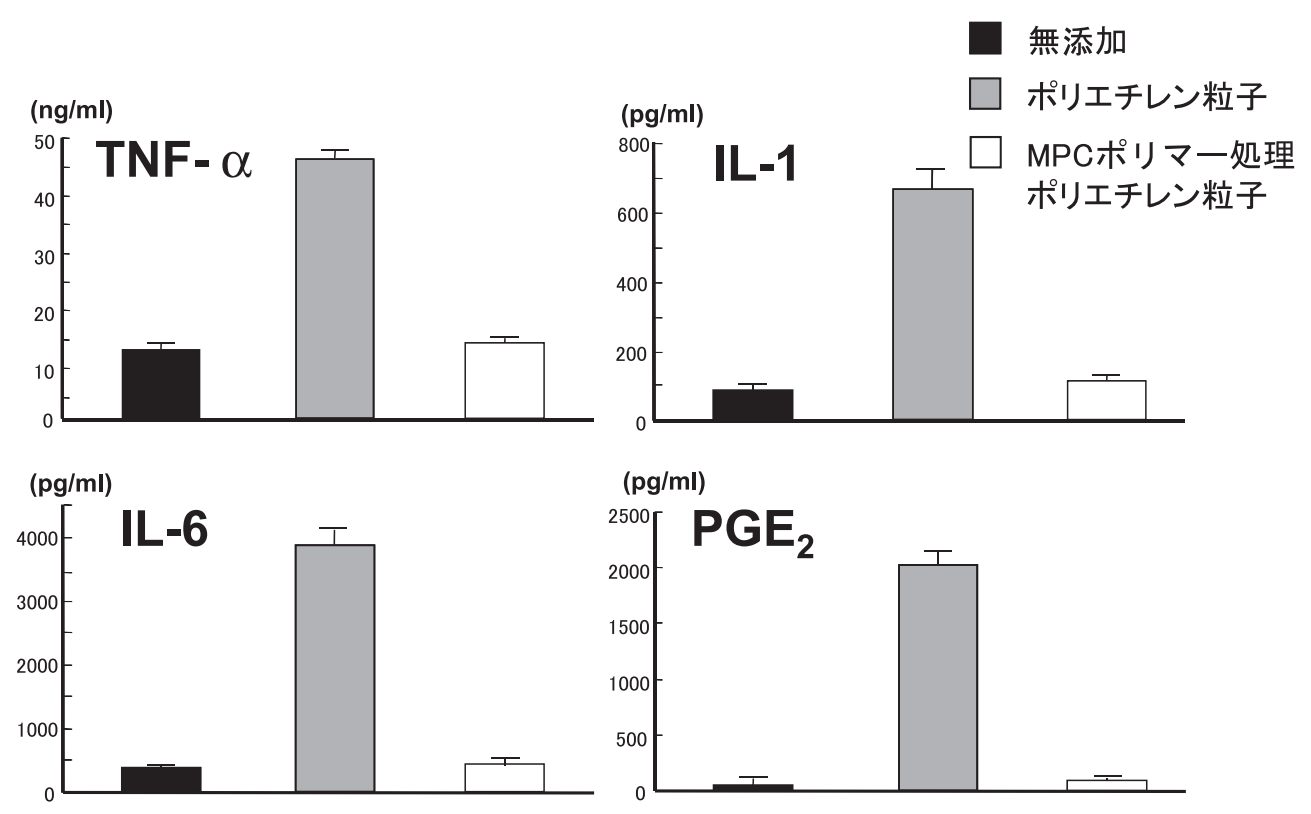

Fig. 6 骨芽細胞に対するポリマー粒子（摩耗粉）の影響。

以上の生体内外での実験結果より，MPC ポリマー粒 子はマクロファージの食食を受けず，破骨細胞の形成． 活性化，骨吸収を誘導しないことが明らかになった。こ のことはポリエチレンの摩耗粉が生じても, まったく生 体系には影響しないことを示しており，破骨細胞の誘起 による人工関節のゆるみを原因より効果的に阻止してい ることを示す。

\section{6 おわりに}

人工股関節摺動面の MPC ポリマー処理は, 弛みの主 因となるポリエチレン摩耗粉の産生を著減させること, 仮に摩耗粉を生じても骨吸収を誘導しないことが明らか になり，従来の人工股関節に扮ける課題が同時に解決で きることが示された。また，MPCポリマー処理方法を 最適化することで, 連続 8,000 万サイクル以上の歩行負 荷（通常の生活にして約 80 年分）をかけても著明な摩 耗抑制効果がみられ，その処理効果も維持されているこ とが明らかとなってきている。これは金属とポリマーを 摺動すると，必ずポリマーが摩耗するというこれまでの 固定概念を根本から覆す結果であり，界面に自由水含率 の高いポリマー層をナノスケールで形成させると高い潤 滑効果が維持でき, 結果としてポリマー側の摩耗が抑制 されるという材料科学的にも興味深い発見である。臨床 応用を考えた場合，MPCポリマーで表面処理したステ ント,カテーテルなどはすでに欧米で認可され，ポリマー としての生体内での安全性が確立されていることは利点 である ${ }^{12)}$ 。また，人工股関節の寿命を飛躍的に延長す る長寿命型人工関節の開発につながり, 手術の適応にな
り難かった若年の症例でも人工股関節手術を選択肢に加 えられるなど, 治療方法の選択を変える画期的な新技術 である。これは東京大学医学部整形外科学教室, および 京セラメディカル株式会社との連携で, 臨床治験を経て 2011 年 4 月に製造承認認可を取得し, 10 月より臨床導 入された。2012 年 11 月現在までに 4,500 例以上の人工 股関節置換術が施されている。

MPC モノマー，ポリマーを世に出すためには多くの 障壁があったが, 一方で幸運であったとも言える。特に 製品とする上で，安全性を重視した施設で工業的規模の 合成をすることが不可欠である。工業所有権は科学技術 振興機構に委託して権利化し，これを日油株式会社にラ イセンスした。1997 年に工業プラントが稼働し，年間 トンのオーダーでモノマー, ポリマーが得られるように なった。研究室で白色結晶ができて10年目であった 6 , 7 。

MPC ポリマーで表面処理した医療デバイス，ソフト コンタクトレンズなどは国外においてすでに臨床応用さ れている。国内でも化粧品原料, コンタクトレンズ保存 液, 臨床検査試薬などでは多くの製品がでている。特に 化粧品原料としては保湿性がヒアルロン酸やコラーゲン を淩駕し，加齢に伴う皮膚機能の低下を抑制するために 国内外の多くの化粧品メーカーが利用している。これは ヒトの皮膚に適合する人工細胞膜表面を作り出している といえよう ${ }^{13)}$ 。

筆者はリン脂質ポリマーを利用して人工細胞膜表面の 適用領域をさらに拡大寸るとともに，今後のバイオテク ノロジーの発展により貢献したいとの願望を持ってい る。人工細胞膜構造の有効性と機能性を材料表面に実装 
できる, 普遍的な表面処理技術として適用できるように， “PC サーフェイステクノロジー”を提案した ${ }^{14)}$ 。まず, 細胞やバイオ分子の非特異的吸着抑制表面を創製し，こ れに選択的に細胞と反応するバイオ分子を導入すること により，あたかも Fig. 2 に示した細胞膜表面の機能を構 築するというものである。PC 基が高度に配列した表面 は，バイオ工学を想定したとき極めて大きな可能性に富 んでいる。バイオ分子や細胞との界面での反応を制御す ることだけでも, バイオチップ, バイオセンサー, バイ オリアクターなどを微小化するためには不可欠な技術と なっている ${ }^{15)}$ 。また再生医療, 組織工学など ES 細胞や それから調製される組織を対象とする場合にも重要であ ることはいうまでもない ${ }^{16)}$ 。

\section{文 献}

1）秋吉一成, 石原一彦, 山岡哲二監修：先端バイオマテ リアルハンドブック, NTS (2012).

2）石原一彦, 塙 隆夫, 前田瑞夫編集（日本バイオマテ リアル学会監修)：バイオマテリアルの基礎, 日本医学 館 (2010)
3）石原一彦：ポリマーバイオマテリアル－先端医療のた めの分子設計－，コロナ社 (2009).

4）京本政之, 茂呂 徹, 石原一彦：表面科学，32, 577 (2011).

5) J. J. Jacobs, et al:: Clin Orthop, 393, 71 (2001).

6) 石原一彦: JST News, 1, 8 (2004).

7) 石原一彦: 現代科学, 2004, 49 (2004).

8) T. B. Kirk, et al:: J Orthop Rheumatol, 6, 21 (1993).

9) T. Moro, T. Konno, K. Ishihara, et al.: Nature Mater, 3 , 829 (2004).

10) K. Ishihara, et al., Colloid Surf B: Biointerfaces, 18, 325 (2000).

11）京本政之, 茂呂 徹, 石原一彦: 人工臓器, 40, 57 (2011).

12) Y. Iwasaki, K. Ishihara: Anal Bioanal Chem, 381, 534 (2005).

13）城井忠洋, 島田邦男, 村田敬重, 石原一彦, 中林宣男： 日油学誌, 48, 577 (1999).

14）石原一彦, 高井まどか, 金野智浩, 渡邊順司：表面, 43, 302 (2005)

15）西澤一樹, 高井まどか, 石原一彦: BIO INDUSTRY, 24, 12 (2007)

16）金野智浩, 石原一彦:医学のあゆみ, 238, 1207 (2011). 